\title{
Emergence of Darwinian theories on evolution of Homo sapiens (Catarrhini: Hominidae) and their relevance for social sciences
}

\author{
Origen de las teorías darwinianas de la evolución de Homo sapiens (Catarrhini: \\ Hominidae) y su importancia para las ciencias sociales
}

\author{
GERMÁN MANRÍQUEZ1,2,3 \\ ${ }^{1}$ Programa de Genética Humana, ICBM, Facultad de Medicina, Universidad de Chile, Av. Independencia 1027, Santiago, Chile \\ ${ }^{2}$ Departamento de Antropología, Facultad de Ciencias Sociales, Universidad de Chile, Santiago, Chile \\ e-mail: gmanriqu@med.uchile.cl
}

\begin{abstract}
Despite the great impact that the Darwinian theories on organic evolution have had in the development and consolidation of biology as an autonomous scientific discipline, their relevance in social sciences, and particularly in archaeology and anthropology still remain ambiguous. This ambiguity is reflected in the classical interpretation of Darwin's work pervading Social Sciences during more than one century, according to which the same ideas that contributed to the understanding of natural processes from a scientific perspective would be at the basis of a misleading interpretation of the evolution of human societies due to the application of the principle of natural selection to the social processes. Here we show how the works of T.H. Huxley and A.R. Wallace positively stimulated Darwin to answer to the question about the origin of human populations considering culture from an evolutionary perspective as a factor opposed to the negative action of natural selection on human societies, thus refuting the classical interpretation of Darwin's work made by Social Sciences. The role played by the biocultural approach in understanding human evolution as well as in promoting the integrative thinking in Social Sciences is also discussed.
\end{abstract}

Key words: Darwin, human evolution, social sciences.

\section{RESUMEN}

A pesar del enorme impacto que las teorías de Darwin sobre la evolución orgánica han tenido en el desarrollo y la consolidación de la biología como disciplina científica autónoma, su pertinencia en ciencias sociales, y particularmente en arqueología y antropología sigue siendo ambigua. Esta ambigüedad se refleja en la interpretación clásica de la obra de Darwin que ha permanecido en las ciencias sociales durante más de un siglo, según la cual las mismas ideas que contribuyeron a la comprensión de los procesos naturales desde una perspectiva científica estarían en la base de una interpretación errónea de la evolución de las sociedades humanas debido a la aplicación del principio de la selección natural a los procesos sociales. Se muestra cómo la obra de T.H. Huxley y A.R. Wallace estimularon positivamente a Darwin para responder a la pregunta sobre el origen de las poblaciones humanas. Esta respuesta consideró a la cultura desde una perspectiva evolutiva y como un factor opuesto a la acción negativa de la selección natural en las sociedades humanas, rechazándose así la interpretación clásica de la obra de Darwin formulada desde las ciencias sociales. Se discute el rol que juega el enfoque biocultural en la comprensión de la evolución humana así como en promover el pensamiento integrativo en las ciencias sociales.

Palabras clave: ciencias sociales, Darwin, evolución humana.

The main aim of this work is to explore the background allowing the emergence of Darwinian theories on evolution of Homo sapiens, as well as to recognize their relevance as tools of integrative thinking in social sciences. For this purpose we will first focus the influence that founders of Social Sciences represented by Herbert Spencer (1820-1903), Emile Durkheim (1858-1917), and Karl Marx (1818-1883) had on the main views that social scientists have had since then on Darwin's evolutionary theories. Secondly, we will show the importance that Darwin's (1809-1882) contemporary naturalists had on the development of his own conceptions about human evolution by revising the works of Thomas Henry Huxley (1825-1895) and Alfred Russel Wallace (1823-1913). Later we will discuss how the approach of biocultural evolution may be considered as a conceptual framework for the social sciences oriented towards an understanding of the role played by 
biological and cultural factors in the study of human evolution. Finally the place of integrative thinking in current physical anthropology and archaeology will be examined.

\section{HERBERT SPENCER AND EMILE DURKHEIM: FIRST STEPS TOWARDS THE \\ MISUNDERSTANDING OF DARWIN IN SOCIAL SCIENCES}

Intra- and interspecific competence for resources, as well as variation and heredity of phenotypical attributes conferring to their carriers a differential of mating, reproduction and/or survival were main arguments used by Charles Darwin to establish his three theories of organic evolution: natural selection (Darwin 1859), sexual selection and descent with modification (Darwin 1871). It is broadly accepted that this theoretical framework changed the theistic and anthropocentric view characteristic of pre-Darwinian times, and that after Darwinian revolution this approach constitutes the basis of the studies on the changes observed in Homo sapiens populations. However, despite the great impact that Darwinian theories on organic evolution have had in the development and consolidation of Biology as an autonomous scientific discipline (Mayr 2004), their influence in social sciences, and particularly in Archaeology and Anthropology still remains ambiguous.

Thus, Darwin's legacy in social sciences would have a twofold nature: one, associated to the author of the theory of natural selection explaining the diversity of living beings by natural causes, corresponding to the "good" Darwin, and the other one characterized by the principle of natural selection applied to human society following the Malthusian principle of imbalance between the growth rates of human populations, and the resources available for their subsistence. According to this particular view, the "bad" Darwin was the one who would have adopted Spencer's idea about natural selection as a process equivalent to the "struggle for existence" having as its most important result "the survival of the fittest". The supposed Darwin's debt to Herbert
Spencer for this contribution has been thoroughly discussed by Haines (1991), who quotes a letter of July 5, 1866, addressed by Darwin to AR Wallace commenting this subject. This, in turn, would have pave the way during the $\mathrm{XX}^{\text {th }}$ Century for the exclusion of Darwinism from the academic circles of Social Sciences in Europe because of its eventual closeness to Herbert Spencer's ideas about the causes of social evolution. Interestingly the reception of Darwin's theories by social thinkers outside Europe was related with political gradualism to promote and justify the Imperial status quo as in Japan (Elshakry 2009), with cooperation and colectivism in the zarist Russia (Todes 2009), or even with political revolution and change of the social conditions as happened in China under the threath of Western imperialism (Pusey 2009), but definitively not with the more familiar to europeans "struggle for existence" principle.

After Spencer evolutionary change had a "cosmic" character consisting in the permanent redistribution of matter and energy because of the principle of the conservation of energy. As a result, the progressive structural similarity and functional complexity of all the matter of the universe was obtained (Hawkins 1997). Moreover, according to this view due to structural similarities derived from the permanent tendency to change, the evolutionary forces acting both upon individuals and upon societies as a whole would be the same. The main tenets derived from this view were that societies consisted of aggregates of individuals, and that the laws explaining evolution of individual organisms were the same laws explaining the behavior of societies. From this perspective, considering warfare as the social equivalent of the individual tendency to struggle for existence was just a natural consequence of the rules of cosmic evolution towards progress and complexity of the matter in universe: "Warfare among men, like warfare among animals, has had a large share in raising their organizations to a higher state" (Spencer 1873, The study of sociology, quoted by Hawkins 1997, p. 85). At which extent Spencer legitimated his political views supporting the role of individual in society against the regulation of civil affaires by the State becomes clear from his 
"Education: Intellectual, Moral and Physical" (1906) (cited by Hawkins 1997, p. 90): "Society is made up of individuals; all that is done in society is done by the combined action of individuals; and therefore in individual actions only can be found the solutions of social phenomena”.

The equivalence proposed by Herbert Spencer between natural selection and struggle for existence, as well as the emphasis given by him to the role played by those factors in social and political evolution were decisive for a vast majority of social scientists to make equivalent Darwinian views on evolution with Spencerian's.

One of the major contributors to reinforce the idea about the natural continuity between Spencer and Darwin evolutionary thoughts in the European tradition of social sciences was Emile Durkheim (1895). His main legacy to social sciences was the foundation of a positivist approach for the better understanding of social phenomena, considering social facts as things, similar to the way physiology, chemistry and physics treat their own subjects of study. In direct allusion to the individualism contained in Spencer's views about social evolution, Durkheim states that "...to understand the way in which a society thinks of itself and of its environment one must consider the nature of the society and not that of the individuals" (Durkheim 1895). And, with regard to the methodological value of Spencer's work, the founder of modern sociology simply asserts that “(...) in the entire work of Spencer the problem of methodology occupies no place, for The Study of Sociology, perhaps a misleading title, is devoted to demonstrating the difficulties and possibilities of sociology, not to expounding the methods it ought to use" (Durkheim 1895). Never having declared it as an explicit purpose, the criticisms made to Spencer's theory of social evolution by the founder of the Paris school of Scientific Sociology (Durkheim 1895) were interpreted as a criticism to Darwin's theory on organic evolution. As will be shown later, the main contribution of Darwin's work to Social Sciences was not directly related to the theory of natural selection (Darwin 1859), but to the theories of sexual selection and descent with modification (Darwin 1871).

\section{KARL MARX AND THE ORIGINS OF HIS CONTROVERSY WITH DARWIN'S WORK ON EVOLUTION}

According to Tort (2002), the origin of the above mentioned dichotomy between the "two Darwin's" would lie in the contradictory opinion that the founders of Marxism had about the contributions of Darwin's theory of natural selection to the understanding of the laws governing nature, and society. The letters exchange between Karl Marx and Friedrich Engels during their long stay in England allows us to illustrate this statement. Two weeks after the first edition of "The Origins..." was already available in London's bookshops, Friedrich Engels wrote to Karl Marx: "Darwin, by the way, whom I'm reading just now, is absolutely splendid. There was one aspect of teleology that had yet to be demolished, and that has now been done. Never before has so grandiose an attempt been made to demonstrate historical evolution in Nature, and certainly never to such good effect. One does, of course, have to put up with the crude English method" (Engels 1859).

A short time after Engels had recognized the materialistic nature of the causes of history of life on the Earth in Darwin's work, and been then already published the third edition of "On the Origins..." (Darwin 1861), Karl Marx severely criticized Darwin for applying the Malthusian views to organic world: "I'm amused that Darwin, at whom I've been taking another look, should say that he also applies the 'Malthusian' theory to plants and animals (...) It is remarkable how Darwin rediscovers, among the beasts and plants, the society of England with its division of labour, competition, opening up of new markets, 'inventions' and Malthusian 'struggle for existence'. It is Hobbes' bellum omnium contra omnes and is reminiscent of Hegel's Phenomenology, in which civil society figures as an 'intellectual animal kingdom', whereas, in Darwin, the animal kingdom figures as civil society" (Marx 1862).

Does the Darwin's "crude English method" disappoint the two German philosophers so much that they completely reverted their initially very favorable impression on the Darwinian work? Does Darwin understand the Malthusian principle just in its simplest form 
(i.e. geometric versus arithmetic rates of growth) as Marx and Engels pretended?

The answer to these questions are to be found in the decade that followed the publication of "On the Origin of Species by Means of Natural Selection, or the Preservation of Favoured Races in the Struggle for Life" (Darwin 1859), when Darwin prepared his book on sexual selection and human evolution. Interestingly this book was never quoted by Karl Marx and Friedrich Engels. The fact that Engels reiterated such concepts in his "Dialectics of Nature", written between 1873 and 1883 (Engels 1974), corroborates this point. The task that Engels set himself in writing this book was to show how the "dialectical laws of motion" can be applied not only to social phenomena but also to the changes observed in Nature. So, it is highly improbable that he have not had notice about the 1871 Darwin's book considering the vast amount of themes tretated by Engels and the importance that he gave to Biology to carry out this task.

\section{DARWINIAN THEORIES ON EVOLUTION OF H. SAPIENS}

Although the issue of human evolution was not made public by Darwin until the appearance of "The Descent of Man and Selection in relation to Sex" (Darwin 1871), he was well aware of it even before the editorial success of his capital work "On the Origin of Species by Means of Natural Selection, or the Preservation of Favoured Races in the Struggle for Life" (Darwin 1859). The interest Darwin had in this topic is reflected in the correspondence with his closest friends and fellows. For instance, in a letter addressed to Thomas H. Huxley in October of 1857, he discussed the relevance of the genealogical system of classification based on the community of descent to understand the racial diversity of Mankind: "Grant all races of man descended from one race; grant that all structure of each race of man were perfectly known-grant that a perfect table of descent of each race was perfectly knowngrant all this, \& then do you not think that most would prefer as the best classification, a genealogical one, even if it did occasionally put one race not quite so near to another, as it would have stood, if allocated by structure alone. Generally, we may safely presume, that the resemblance of races \& their pedigrees would go together" (Darwin 1857). Likewise, answering the reception of Alfred Russel Wallace's paper on the origin of human races and the antiquity of man (Wallace 1864), Darwin regretted not having dedicated more time and efforts to the study of that topic: "I have collected a few notes on man but I do not suppose I shall ever use them. Do you intend to follow out your views, \& if so would you like at some future time to have my new references \& notes? I am sure I hardly know whether they are of any value \& they are at present in a state of chaos. There is much more that I should like to write but I have not strength" (Darwin 1864). In similar terms Darwin answered to the envoy made by Charles Lyell of a prepublication copy of his essay on the geological evidences of the antiquity of man: "I have just received the great book (...) I have read last chapter with very great interest (...) You will, I feel sure, give the whole subject of change of species an enormous advance (...) Your book looks beautiful \& I am impatient to begin reading it; but I must get a little more strength." (Darwin 1863). With regard to Thomas Huxley's book on anatomical affinities between man and great apes, Darwin was clearly more enthusiastic: "Hurrah the Monkey Book has come-very many for your present of it. I long to read it, but am determined to refrain till I have finished Lyell, \& I have got only half through it. The Pictures are splendid" (Darwin 1863b).

Considering the content and dates of this correspondence we suggest that Darwin's views on human evolution were stimulated by the corpus of hypotheses developed by some of the leading naturalists of England and continental Europe under the direct influence of the theory of evolution by natural selection. To this corpus -defined hereafter as Darwinian theories on human evolution- belongs Huxley's book "Evidence as to Man's place in nature" (1863), Wallace's address to the Anthropological Society of London "The Origin of Human Races and the Antiquity of Man deduced from the theory of Natural Selection" (1864), and in a lesser degree due to its extreme caution and uncertainty regarding the role of natural selection, Lyell's essay "The 
Geological Evidences of the Antiquity of Man, with remarks on theories of the origin of species by variation" (1863). Although Ernst Haeckel's two volume "Die Natürliche Schöpfungsgeschichte” (1868) make explicit mention to Darwin's work and were dedicated almost completely to the problem of natural (mechanistic) causes of human evolution, the English translation only appeared in 1876, one year after Darwin published the second edition of his "The Descent of Man...". Regarding this point, Darwin (1875) realized: "If this work had appeared before my essay had been written, I should probably never have completed it. Almost all the conclusions at which I have arrived I find confirmed by this naturalist, whose knowledge on many points is much fuller than mine".

\section{T.H. HUXLEY AND THE BIOLOGICAL EVIDENCES ON HUMAN EVOLUTION}

Darwin's recognition of the importance that these works had for the publication of "The Descent of Man..." is expressed in the preface to the first edition (Darwin 1871) as well as in the preface and in the abundant notes added to the second edition of this book, where a comparative study about the structure and function of brain in man and apes by Thomas H. Huxley was included at the end of the chapter dedicated to "The formation of races" (Darwin 1875). Considering the short time between the publication of the first edition of "The Origin..." and the Huxley's and Wallace's works, it seems that the last represented a conscious effort made to fill the gap left by Darwin on this matter in the last chapter of "The Origin...". This gap was reflected in the well known phrase "Light will be thrown on the origin of man and his history", the only public reference made by Darwin about human evolution before the publication of "The Descent of Man...”. Thus, from 1860 and thereafter the less Darwin was explicitly concerned with the issue of human evolution, the more it stimulated his followers and commentators to pave the way with the arguments that finally led him to confront more freely this complex for the Victorian times issue. Then, what were the specific contributions made by Huxley and Wallace to the consolidation of Darwin's views on human evolution?

The problem posed by Huxley had its origin in Richard Owen's statement about the taxonomical classification of Man as a subclass separate from anthropoid apes. Owen presented his conclusions on the comparison of the brain structures of representative species of Homo and Pithecus in a lecture on the classification of mammals delivered at Cambridge University in May 1859. Huxley presented his critique in a paper published in the first number of the new series of the "Natural history review: A quarterly journal of biological science”, under Huxley's general editorship, which appeared in January 1861 (Darwin 1861b). Major topics treated in this publication were developed later in detail by Huxley (1863) in the "Monkey book". According to Huxley (1863), the structural affinities at embryonary stages between man and big apes constitute a strong demonstration of the principle of homology and the theory of descent with modification from a common ancestor stated by Darwin in "The Origins...": "The question of questions for mankind -the problem which underlies all others, and is more deeply interesting than any other- is the ascertainment of the place which Man occupies in nature and of his relations to the universe of things (...) Thus the study of development affords a clear test of closeness of structural affinity (...) It is only quite in the later stages of development that the young human being presents marked differences from the young ape, while the latter departs as much from the dog in its development, as the man does. Startling as the last assertion may appear to be, it is demonstrably true, and it alone appears to me sufficient to place beyond all doubt the structural unity of man with the rest of the animal world, and more particularly and closely with the apes" (Huxley 1863).

Evidences of the genealogical relationship between man and great apes were, among other, the number of teeth in the adult condition, the relative position of the nostrils in the face characteristic of catarrhine apes, their common geographical origin in the old world. The detailed anatomical comparison between man and great apes made by Huxley allowed Darwin to conclude that "(...) in every visible character man differs less from the 
higher apes, than these do from the lower members of the same order Primates" (Darwin 1875). One of the main consequences derived from the Darwinian principle of homology applied to Man was Huxley's inference of human evolution as a fact explained by the gradual modification of ape-like ancestral human populations originated in Africa. This inference was incorporated by Darwin as one of the biogeographical evidences of the evolutionary ancestry of man with catharrines: "In each great region of the world the living mammals are closely related to the extinct species of the same region. It is therefore probable that Africa was formerly inhabited by extinct apes closely allied to the gorilla and chimpanzee; and as these two species are now man's nearest allies, it is somewhat more probable that our early progenitors lived on the African continent than elsewhere." (Darwin 1875: Chapter VI).

\section{A.R. WALLACE AND THE RELATIONSHIP BETWEEN CULTURE AND NATURAL SELECTION}

Regarding A.R. Wallace's contribution to the Darwinian theories on human evolution, it is related to the causes explaining the origin of morphological variation observed in human populations, i.e. the monophyletic vs. polyphiletic hypotheses: "is man of one or many species?” (Wallace 1864). To answer this question Wallace applied the principle of Natural Selection: "It is my wish to show how the two opposing views can be combined so as to eliminate the error and retain the truth in each, and it is by means of Mr. Darwin's celebrated theory of "Natural Selection" that I hope to do this, and thus to harmonise the conflicting theories of modern anthropologists" (Wallace 1864).

After explaining the conditions to observe the effects of natural selection in the organic world (heredity, variation, and changing conditions of life), Wallace remarked the main differences existing between man and the rest of animals in relation to the way they respond to the action of natural selection. According to Wallace, these differences were mainly associated to the capacity of "checking" the negative effects of natural selection through social and cooperative behaviour: “(...) [Man] is social and sympathetic. In the rudest tribes the sick are assisted at least with food; less robust health and vigour than the average does not entail death (...) The action of natural selection is therefore checked; the weaker, the dwarfish, those of less active limbs, or less piercing eyesight, do not suffer the extreme penalty which falls upon animals so defective" (Wallace 1864).

This "checking" process has two main components. First, the bigger changes of human beings in their "mental and moral qualities" compared to the shifts occurred in their corporal structures. As a result populations having the capacity for acting in concert, assisting each other and showing behaviors benefiting the well-being of all its members would have an advantage in the struggle for life over other groups in which such behaviors are not present. The issues of "mental qualities" and "sympathetic" social instincts "checked" by natural selection were introduced in "The Descent of Man..." by Darwin making direct reference to Wallace's paper. A second component of the conscious effort of human populations to avoid the effects of natural selection is represented by the domestication of plants and animals, broadly considered by Darwin in "The variation of animals and plants under domestication" (Darwin 1868). Noteworthy this subject was also treated by Wallace before the publication of Darwin's book on domestication: “(...) in two distinct ways has man escaped the influence of those laws which have produced unceasing change in the animal world. By his superior intellect he is enabled to provide himself with clothing and weapons, and by cultivating the soil to obtain a constant supply of congenial food. This renders it unnecessary for his body, like those of the lower animals, to be modified in accordance with changing conditions-to gain a warmer natural covering, to acquire more powerful teeth or claws, or to become adapted to obtain and digest new kinds of food, as circumstances may require. By his superior sympathetic and moral feelings, he becomes fitted for the social state; he ceases to plunder the weak and helpless of his tribe; he shares the game which he has caught with less active or less fortunate hunters, or exchanges it for weapons which even the sick or the deformed can fashion; he saves the sick and wounded 
from death; and thus the power which leads to the rigid destruction of all animals who cannot in every respect help themselves, is prevented from acting on him" (Wallace 1864).

\section{BIOCULTURAL EVOLUTION AS A CONCEPTUAL FRAMEWORK FOR THE SOCIAL SCIENCES}

Since Darwin evolutionary change in Homo sapiens (Catarrhini: Hominidae) has been thoroughly studied from various disciplinary perspectives, particularly from the most influential scholar traditions in biology, archaeology and anthropology. Certainly, each of these fields has yielded important contributions to the knowledge of the causes of human evolution. Examples of these contributions are the screening and analysis of human variation from a genetic perspective (International Human Genome Sequencing Consortium 2001), the reconstruction of the cultural and ecological impact that the hominid lineage has had out of Africa (reviewed by Lewin \& Foley 2004), and the evaluation of the pathological consequences of landmark changes in the history of humankind such as the transition from foraging to farming and agriculture (Larsen 1995). However, many archaeologists and anthropologists have expressed their concern about the lack of a more integrative approach to face the complexity of the changes registered in human societies, both past and present (Dressler 1995, McElroy 1990). Thus, the term "biocultural evolution" has emerged during the last two decades as a key idea encapsulating a new conceptual framework for the social sciences oriented towards the understanding of the role played by biological and cultural factors in the evolution of human populations (Dufour 2006, Shennan 2008).

A similar situation has affected Life Sciences in relation to questions demanding a more complex approach than the unilateral biological/genetic determinism. Some examples of this kind of questions are: did cultural challenges occurring between the Middle and the Upper Paleolithic play any role in the biological origin of modern humans' anatomy? (Carbonell \& Vaquero 1998); did the cattle domestication that occurred in Northern Europe 6000 years ago have any effect on the frequency of lactose intolerance found among modern adult populations? (Beja-Pereira et al. 2004) and, is there any relationship between the origin of clothing and the co-evolution between archaic $H$. sapiens populations and an obligate ectoparasite such as the human head louse Pediculus humanus? (Kittler et al. 2003). In all these cases, as in many other of similar complexity, the answer is closely related to the fact that the evolution of hominid representative species, and not only of $H$. sapiens, is of a biocultural nature, expressed by anatomical and morpho-functional novelties such as bipedalism, encephalization, development of language and basic socialization skills followed by sudden and abrupt cultural changes (i.e. domestication of fire, plants and bovids). In this sense the concept of biocultural evolution emerging from the biological disciplines is considered as corresponding to a factual process of change and not only to a model or to an approach used in assessing the process itself (Fracchia \& Lewontin 1999). Consequently, it is not trivial to note that behind this last meaning lies the idea of integration as pivotal for biocultural studies. As expressed by McElroy (1995) "integrative thinking means rethinking basic assumptions, asking new questions, challenging existing theories, and forging new methods. It means moving flexibly between biological and cultural realms in an era that rewards specialization... It is fairly easy to include both biological and cultural variables in research designs for heuristic purposes, but to operationalize the variables and to carry out systematic collection of both cultural and biological data is a more challenging task".

Following McElroy statement we think that the critical assessment of the contributions and limitations of Darwinian evolutionary theories about human evolution represents a first but necessary effort addressed to better understand the relevance of the biocultural approach for the development of an integrative thinking in Social Sciences.

MULTIDISCIPLINARY RESEARCH IN PHYSICAL ANTHROPOLOGY AND ARCHAEOLOGY: THE ROLE OF INTEGRATIVE THINKING

Physical anthropology and archaeology defined their theoretical background and 
methodological tools at the very beginning of their foundations. Together with Sociology they constituted core academic fields of the emerging Social Sciences during the $19^{\text {th }}$ Century (Cuvier 1800, Durkheim 1895). Instead of being concerned with the causes of processes occurring at the cosmic (Gauss 1809, Laplace 1843), planetary (Lyell 18301833), organic (Lamarck 1809, Darwin 1859, Mendel 1865) or even atomic (Lavoisier 1789, Mendelejiev 1868) levels, the focus of Physical Anthropology and Archaeology was centered on the study of overall anatomical diversity, cultural legacy and evolution of human societies. As in every new area of scientific knowledge this initial distinction represented a positive stimulus for the development of the disciplinary identity of the field. However, since then many archaeologists and anthropologists have discussed the scope of Social Sciences in relation with the classic scholar traditions of natural sciences (i.e. biology, geology, physics and chemistry), and what role, if any, the latter play in anthropology and archaeology. According to of one of the most influencial voices of $20^{\text {th }}$ Century Anthropology (Lévi-Strauss 1967 cit. Bossert 1982) this discipline "has, as it were, its feet planted on the natural sciences, its back resting against the humanistic studies and its eyes directed toward the social sciences". Despite its importance, we don't pretend to discuss the impact on Social Sciences of the theoretical developments occurred during the last decades in natural sciences such as evolutionary biology or genetics (reviewed by Bamforth 2000, Gould 1988, Lewontin et al. 1984, Wilson 1975). Rather, and following Lévi-Strauss' metaphor, we are interested in showing how Darwinian evolutionary theories about human evolution, multidisciplinary research and integrative thinking can contribute to develop a more direct and fluid relationship between the "eyes", and the "feet" of the main scholar traditions of social sciences. Current anthropology and archaeology multidisciplinarity is clearly reflected in the questions posed by many university centers in their respective undergraduate introductory courses: Where do modern humans come from? When and how did agriculture begin? What is "complex society" and when did it start? (Harvard University 2007), What makes us human? Is there such a thing as human nature? Why are human societies so different from other societies? How do we find out about the past at times when there was no writing? (University of Cambridge 2009), Did Neanderthals sing as they buried their dead? Have societies really evolved from simple to complex? How can archaeologists date objects from the past? How can we reconstruct past climates and ecologies and can this tell us anything about possible future patterns of environmental change? (Oxford University 2009). A similar approach can be found in the programme of international meetings and congresses in Archaeology and Anthropology. For example, the Sixth World Archaeological Congress held recently in Dublin listed "Archaeology in the Digital Age 2.0", "Our Changing Planet: Past Human Environments in Modern Contexts", "Rainforest as Artefact", and "Emerging Global Archaeologies" as outstanding themes (WAC-6 2008).

These questions, undoubtedly, represent the influence that Darwin's work has had during the last Century on two of the most fast developing disciplines of current Social Sciences. Time will come for the integration of new areas.

\section{CONCLUSIONS}

The works of T.H. Huxley and A.R. Wallace positively stimulated Darwin to answer to the question about the origin of man from a primate ancestor living in Africa, as well as to consider culture from an evolutionary perspective as a factor opposed to the negative action of natural selection on human societies.

This view is opposed to the classical interpretation of Darwin's work pervading Social Sciences during more than one century, according to which Darwin ideas contributed to an erroneous interpretation of the evolution of human societies due to the application of the principle of natural selection to social processes.

The biocultural approach based on Darwinian theories about human evolution may be one of the conceptual frameworks necessary for the development of an integrative thinking in Social Sciences. 


\section{AKNOWLEDGEMENTS}

I am grateful to Dr. Valentina Figueroa from Université de Paris I, Panthéon-Sorbonne, for sharing her views and knowledge about the dialectical nature of the effect of natural selection in human populations and to Dr. Herman Niemeyer from Universidad de Chile, for the stimulating discussions about the relationship between biology and culture. This work was partially supported by grant Programa de Investigación Asociativa Anillos en Ciencia y Tecnología ACT N ${ }^{\circ} 096$ (GM) (http:// www.cienciaymemoria.cl).

\section{LITERATURE CITED}

BAMFORTH DB (2002) Evidence and metaphor in evolutionary archaeology. American Antiquity 67: 435-452.

BEJA-PEREIRA A, G LUIKART, PR ENGLAND, DG BRADLEY, OC JANN et al. (2004) Gene-culture coevolution between cattle milk protein genes and human lactase genes. Nature Genetics 35: 311-313.

BOSSERT PJ (1982) Philosophy of man as a rigorous science: A view of Claude Lévi-Strauss Structural. Anthropology. Human Studies 5: 97107.

CARBONELL E \& M VAQUERO (1998) Behavioral complexity and biocultural change in Europe around forty thousand years ago. Journal of Anthropological Research 54: 373-398.

DARWIN CR (1857) Letter to Thomas H. Huxley, 3 October 1857. Darwin Correspondence Project, University of Cambridge, UK. URL: http:// www.darwinproject.ac.uk/ (accessed October 1, 2009).

DARWIN CR (1859) The origin of species by means of natural selection or the preservation of favoured races in the struggle for life. John Murray, London.

DARWIN CR (1861) The origin of species by means of natural selection or the preservation of favoured races in the struggle for life. Third edition. John Murray, London.

DARWIN CR (1861b) Letter to T.H. Huxley, 3 January 1861. Darwin Correspondence Project, University of Cambridge, UK. URL: http:// www.darwinproject.ac.uk/ (accessed October 1, 2009).

DARWIN CR (1863a) Letter to Ch. Lyell, 4 February, 1863. Darwin Correspondence Project, University of Cambridge, UK. URL: http:// www.darwinproject.ac.uk/ (accessed October 1, 2009).

DARWIN CR (1863b) Letter to Th. Huxley, 18 February, 1863. Darwin Correspondence Project, University of Cambridge, UK. URL: http:// www.darwinproject.ac.uk/ (accessed October 1, 2009).

DARWIN CR (1864) Letter to A.R. Wallace, 28 March, 1864. In: Burkhardt F, S Evans \& A Pearn (eds) Evolution. Selected letters of Charles Darwin 186-1870. Cambridge University Press, Cambridge.

DARWIN CR (1868) The variation of animals and plants under domestication. John Murray, London.
DARWIN CR (1871) The descent of man and selection in relation to sex. John Murray, London.

DARWIN CR (1875) The descent of man and selection in relation to sex. Second edition. John Murray, London.

DRESSLER WM (1995) Modeling biocultural interactions: Examples from studies of stress and cardiovascular disease. Yearbook of Physical Anthropology 38: 27-56.

DUFOUR DL (2006) Biocultural approaches in human biology. American Journal of Human Biology 18: 1-9.

DURKHEIM E (1895) The rules of sociological method. Eight edition. Translated by Solovay SA \& JH Mueller, 1938. The Free Press of Glencoe, Collier-Macmillan Limited, London.

ELSHAKRY M (2009) Global Darwin: Eastern enchantment. Nature 461: 1200-1201.

ENGELS F (1859) Marx-Engels correspondence; Engels to Marx in London, 11-12 th December, 1859. Marxists Internet Archive. URL: http:// www.marxists.org/archive/marx/works/1859/ letters/59_12_11.htm (accessed November 12, 2009).

ENGELS F (1974) Dialectics of nature. Progress Publishers, Moscow.

FRACCHIA J \& RC LEWONTIN (1999) Does culture evolve? History and Theory, Theme Issue 38: 5278.

GOULD SJ (1988) La falsa medida del hombre. Ed. Orbis, Buenos Aires.

HAECKEL E (1868) Natürliche schöpfungsgeschichte: Gemeinverständliche wissenschaftliche vorträge über die entwickelungslehre im allgemeinen und diejenige von Darwin, Goethe und Lamarck im besonderen, über die anwendung derselben auf den ursprung des menschen und andere damit zusammenhängende grundfragen der naturwissenschaft. Georg Reimer, Berlin.

HAINES VA (1991) Spencer, Darwin, and the question of reciprocal influence. Journal of the History of Biology 24: 409-431.

HARVARD UNIVERSITY (2007) Anthropology 1010 Introduction to archaeology fall 2007. Department of Anthropology. URL: http:// www.courses.fas.harvard.edu/ anth1010/ (accessed October 1, 2009)

HAWKINS M (1997) Social Darwinism in European and American thought 1860-1945: Nature as a model and nature as threat. Cambridge University Press, Cambridge.

HUXLEY TH (1863) Evidence as to man's place in nature. Williams and Norgate, London.

INTERNATIONAL HUMAN GENOME SEQUENCING CONSORTIUM (2001) Initial sequencing and analysis of the human genome. Nature 409: 860921.

KITTLER R, M KAYSER \& M STONEKING (2003) Molecular evolution of Pediculus humanus and the origin of clothing. Current Biology 13: 14141417.

LAMARCK JB (1809) Philosophie zoologique. GFFlammarion, Paris [1994].

LAPLACE PS (1843) Traité de mécanique céleste. In: Ouvres de Laplace. Tome premier. Imprimerie Royal, Paris.

LARSEN CS (1995) Biological changes in human populations with agriculture. Annual Review of Anthropology 24: 185-213.

LAVOISIER AL (1789) Traité élémentaire de chimie. 
Seconde édition. Cuchet Libraire, Rue \& Hotel Serpente, Paris.

LEWIN R \& RA FOLEY (2004) Principles of human evolution. Second edition. Willey-Blackwell, Malden, USA

LEWONTIN RC, S ROSE \& LJ KAMIN (1985) Not in our genes. Biology, ideology and human nature. Pantheon Books, New York.

LYELL Ch (1830-1833) Principles of geology. Pinguin Books, London [1997].

LYELL Ch (1863) The geological evidences of the antiquity of man, with remarks on theories of the origin of species by variation with remarks on theories of the origin of species by variation. Second edition. GW Childs Publishers, Philadelphia.

MARX K (1862) Marx-Engels correspondence, Marx to Engels in Manchester, 18 June 1862. Marxists Internet Archive. URL: http:// www.marxists.org/archive/marx/works/1862/ letters/62_06_18.htm (accesed November 12, 2009).

MAYR E (2001) What evolution is. Basic Books, New York.

McELROY A (1990) Biocultural models in studies of human health and adaptation. Medical Anthropology Quarterly New Series 4: 243-265.

MENDEL G (1865) Versüche über Pflanzen-Hybriden. Verhandlungen des naturforschenden Vereins. Brünn, Band IV. S. 3-47.

MENDELEJIEV DI (1869) The dependence between the properties of the atomic weights of the elements. Proceedings of the Russian Chemical Society V. 3.

OXFORD UNIVERSITY (2009) School of Archaeology. BA Archaeology \& Anthropology URL: http:// www.arch.ox.ac.uk/prospective_students/ ba_archaeology_and_anthropology (accessed October 4, 2009).

PUSEY J (2009) Global Darwin: Revolutionary road. Nature 462: 162-163.

TODES D (2009) Global Darwin: Contempt for competition. Nature 462: 36-37.

TORT P (2002) La seconde révolution darwinienne: Biologie evolutive et théorie de la civilisation. Editions Kimé, Paris.

SHENNAN S (2008) Evolution in archaeology. Annual Review of Anthropology 37: 75-91.

UNIVERSITY OF CAMBRIDGE (2009) Tripos in archaeology and anthropology. URL: http:// www.cam.ac.uk/admissions/undergraduate/ courses/archanth/ (accessed October 2, 2009).

WAC-6 (2008) Sixth World Archaeological Congress, Dublin - Ireland. URL: http://www.ucd.ie/wac6/index.html (accessed October 3, 2009).

WALLACE AR (1864) The origin of human races and the antiquity of man deduced from the theory of "natural selection". Journal of the Anthropological Society of London 2: 158-187.

WILSON EO (1975) Sociobiology. The new synthesis. Harvard University Press, Cambridge, Massachusetts, USA. 